\title{
Manipulasi Handycam sebagai Kamera Citra Termal untuk Deteksi Dini Kanker Payudara dengan Metode Images Processing menggunakan Matlab
}

\author{
Rio Riantana, ${ }^{1, *}$ Berton Arie, ${ }^{2}$ Muhammad Adam, ${ }^{2}$ dan Nuryani ${ }^{1}$ \\ ${ }^{1}$ Program Studi Fisika,Fakultas Matematika dan Ilmu Pengetahuan Alam \\ Universitas Sebelas Maret Surakarta Jl. Ir. Sutami No.36A Kentingan, Surakarta 57126 \\ ${ }^{2}$ Program Studi Informatika, Fakultas Matematika dan Ilmu Pengetahuan Alam \\ Universitas Sebelas Maret Surakarta, Jl. Ir. Sutami No.36A Kentingan, Surakarta 57126
}

\begin{abstract}
Intisari
Dalam mendeteksi gejala awal dari kanker payudara, salah satu hal penting yang harus diwaspadai adalah perubahan temperatur payudara. Naiknya temperatur payudara ternyata merupakan indikasi gejala ketidaknormalan jaringan payudara. Prinsip dari project ini adalah merubah citra infra merah yang berupa grayscale (citra abu-abu) menjadi citra termal (temperatur) yang berupa polikromatik (warna-warni), dengan cara memecah citra grayscale menjadi matriks kode per pixel lalu menggabungkannya kembali dan ditampilkan dalam skala warna. Handycam pada mode night vision yang diberi interferensi infrared eksternal dapat melakukan penetrasi ke kulit lebih baik dan dapat menjadikan citra infra merah menjadi lebih jelas. Program PERKARA mampu mengubah gambar hitam-putih dari handycam menjadi citra termal dengan cara memecah struktur matriks RGB menjadi grayscale. Setelah itu matriks disusun ulang pada matriks baru dengan tipe data double sehingga dapat diproses menjadi grafik kontur warna yang dapat membedakan distribusi temperatur tubuh pada citra yang diolah. Pengolahan grafik tersebut dengan cara membedakan tingkat keabu-abuan citra tersebut sehingga didapatkan warna yang berbeda-beda. Pada Program Perkara terdapat pula fitur pengaturan skala kontras pada citra yang diolah sehingga kedetilan warna dapat diatur sesuai keinginan. Selain itu juga ada fitur pengaturan skala kontras invers yang berguna untuk membalik skala warna sehingga warna dapat berubah menjadi sebaliknya.
\end{abstract}

\section{ABSTRACT}

In detecting early symptoms of breast cancer, one of the important things to wary is changes of temperature of the breast. Increasing temperatures breast was an indication of the symptoms of breast tissue abnormalities. The principle of this project is to change the infrared image form of grayscale to thermal image in the form polychromatik (colorful), by breaking the grayscale image into a matrix of code per pixel and combines back and displayed in scale color. Handycam in night vision mode by the interference of external infrared can penetrate into the skin better and can make an infrared image becomes clearer. Program PERKARA is able to change the black and white images from a camcorder into a thermal image by breaking into Grayscale RGB matrix structure. Once the matrix is rearranged in the new matrix with double data type so that it can be processed into contour color chart to differentiate the distribution of body temperature in the processed image. The graphics processing by differentiating levels of gray of the image to obtain different colors. In Program PERKARA are also features of a scale setting the contrast of the image is processed so that the color of detail can be set as desired. There was also a contrast adjustment feature inverse scale that is useful to reverse the color scale so that colors can be changed into its opposite.

KATA KUNCI: kanker payudara, images processing, matlab, infrared http://dx.doi.org/10.12962/

\section{PENDAHULUAN}

Kanker payudara adalah suatu penyakit dimana terjadi pertumbuhan berlebihan atau perkembangan tidak terkontrol dari sel-sel jaringan payudara [1]. Kanker payudara merupakan jenis kanker yang sering ditemukan oleh kebanyakan wanita. Bahkan, di Indonesia, kanker tertinggi yang diderita wanita Indonesia adalah kanker payudara [2]. Bagi wanita di bawah

*E-MAIL: rioriantana@yahoo.com
30 tahun, para dokter menyarankan untuk melakukan tes MRI (Magnetic Resonance Imaging). MRI tidak menggunakan radiasi sinar-X dan cocok untuk mendeteksi jaringan lunak. Namun, pencitraan dengan MRI lebih mahal sehingga sedikit sekali wanita yang melakukan tes MRI.

Selain melakukan tes MRI, tes mammogram (mammografi) banyak dilakukan oleh mayoritas kalangan wanita dalam mendeteksi adanya kanker payudara. Mammografi adalah pemeriksaan payudara manusia menggunakan sinar- $\mathrm{X}$ dosis rendah (umumnya berkisar $0,7 \mathrm{mSv}$ ). Namun, berbagai pihak masih meragukan penggunaan mammografi karena tingkat kesalahan yang masih tinggi dan karena radiasi yang digu- 


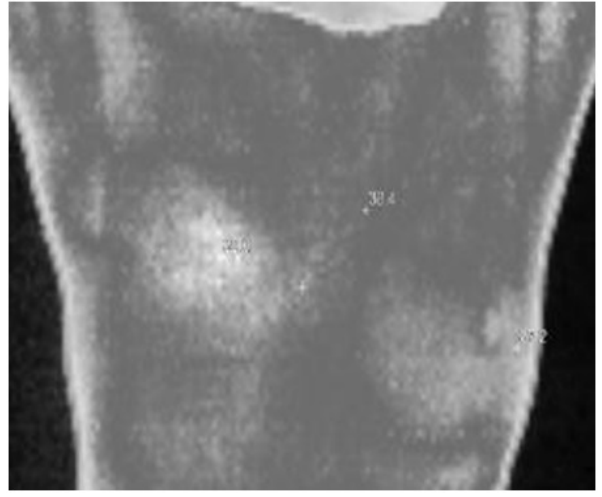

(a)

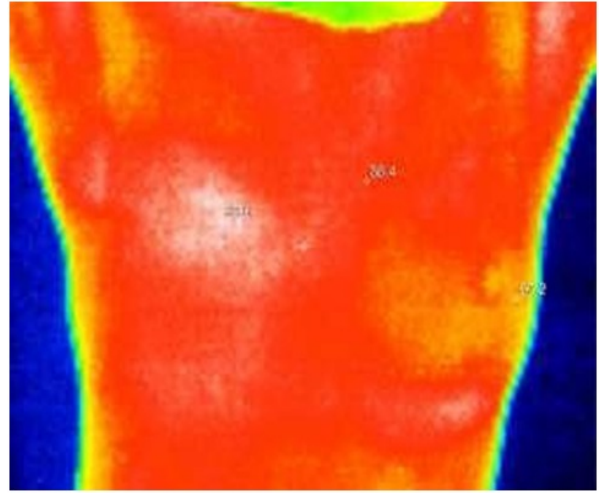

(b)

Gambar 1: (a)gambar grey scale, (b)gambar polikromatis.

nakan dapat menimbulkan bahaya.

Dalam mendeteksi gejala awal dari kanker payudara, salah satu hal penting yang harus diwaspadai adalah perubahan temperatur payudara. Naiknya temperatur payudara ternyata merupakan indikasi gejala ketidaknormalan jaringan payudara. Maka dari itu kami memiliki gagasan untuk memanipulasi kamera handycam sebagai kamera citra termal untuk deteksi dini kanker payudara dengan metode images processing menggunakan matlab. Sistem ini lebih sederhana dan sangat lebih aman daripada sistem mamografi ataupun MRI.

Pengukuran atau pemrosesan dan akuisisi informasi temperatur tanpa kontak dengan objek yang akan di proses [3]. Pengukuran didasarkan radiasi inframerah dari gelombang elektromagnetik dengan panjang gelombang yang lebih panjang dari cahaya tampak. Objek yang mempunyai temperatur lebih dari temperatur mutlak memancarkan gelombang inframerah [4]. Pengukuran inframerah memerlukan radiasi inframerah dari objek dan di tranformasikan menjadi sinyal listrik. Alat pengubah dasar adalah pyrometer yang menghasilkan sinyal output dengan menggunakan sensor tunggal. Alat yang lebih canggih dapat menghasilkan baris dari hasil pengukuran secara detail dari gambar yang diproduksi. Perbedaan pembacaan cahaya tampak dan inframerah adalah dari sumber cahaya yang menyertainya. Gambar yang memanfaatkan kamera inframerah mengubah menjadi gambar dengan warna berdasarkan tingkat energi inframerah. Gambar hasil dari pembacaan inframerah adalah termogram [5]. Pengukuran menggunakan radiasi menghasilkan pembacaan temperatur dari radiasi yang ditimbulkan. Pembacaan temperatur memiliki kelebihan yaitu secara langsung, tidak merusak, dan aman untuk diulangi setiap waktu [6].

Pembagian atau segmentasi merupakan tahap pertama dari pemrosessan gambar. Gambar dibagi menjadi menjadi beberapa bagian yang memiliki daerah yang sama seperti warna, teksture, kecerahan [7]. Secara matemetik pembagian gambar dapat dibagi menjadi piksel atau matrik dengan keadaan tertentu [8]. Jika $\mathrm{F}$ adalah gambar dengan piksel dan $\mathrm{H}$ adalah bagiah yang sama, maka:

$$
\begin{aligned}
\bigcup_{i=1}^{n} R_{i} & =F \\
R_{i} \bigcap R_{j} & =\phi, i \neq j \\
\text { if } R_{i} & \text { is adjacent to } R_{j} \text { and } H\left(R_{i}\right)=\text { true and } \\
H\left(R_{j}\right) & =\text { true then } H\left(R_{i} \bigcup R_{J}\right)=\text { false }
\end{aligned}
$$

\section{METODE PENELITIAN}

Mekanisme dari manipulasi kamera handycam sebagai kamera citra termal untuk deteksi dini kanker payudara dengan metode images processing menggunakan matlab sedikit rumit. Hal ini dikarenakan proses untuk memanipulasi handycam menjadi kamera termal tidaklah mudah. Perubahan fungsi tersebut tidak dilakukan secara fisik, melainkan menggunakan manipulasi pada perangkat lunak, sehingga citra infra merah pada handycam dapat dirubah menjadi citra termal pada program baru.

Prinsip dari project ini adalah merubah citra infra merah yang berupa grayscale (citra abu-abu) menjadi citra termal yang berupa polikromatik, dengan cara memecah citra grayscale menjadi matriks kode per pixel lalu menggabungkannya kembali dan ditampilkan dalam skala warna. Proses pemotretan dilakukan pada ruang gelap agar tidak terjadi interferensi cahaya selain dari cahaya infra merah. Pasien tidak diperkenankan menggunakan pakaian karena akan menghalangi obyek utama. Setelah gambar didapat maka dilakukan pengolahan citra.

Pada prinsipnya gambar dari foto infra merah yang berupa grayscale memiliki level keabu-abuan, sehingga tiap titik memiliki nilai seberapa abu-abu pixel tersebut. Nilai keabuabuan ini dirubah ke bentuk angka. Agar data citra tidak kacau, maka identitas posisi pixel diberikan dengan format $\mathrm{x}$, $\mathrm{y}, \mathrm{z}$ dimana $\mathrm{x}$ adalah posisi pixel pada sumbu $\mathrm{x}, \mathrm{y}$ adalah posisi pixel pada sumbu $\mathrm{y}$, dan $\mathrm{z}$ adalah nilai dari keabuabuan titik pixel tersebut. Setelah itu data identitas tersebut disusun kembali pada posisinya dengan memberikan skala 


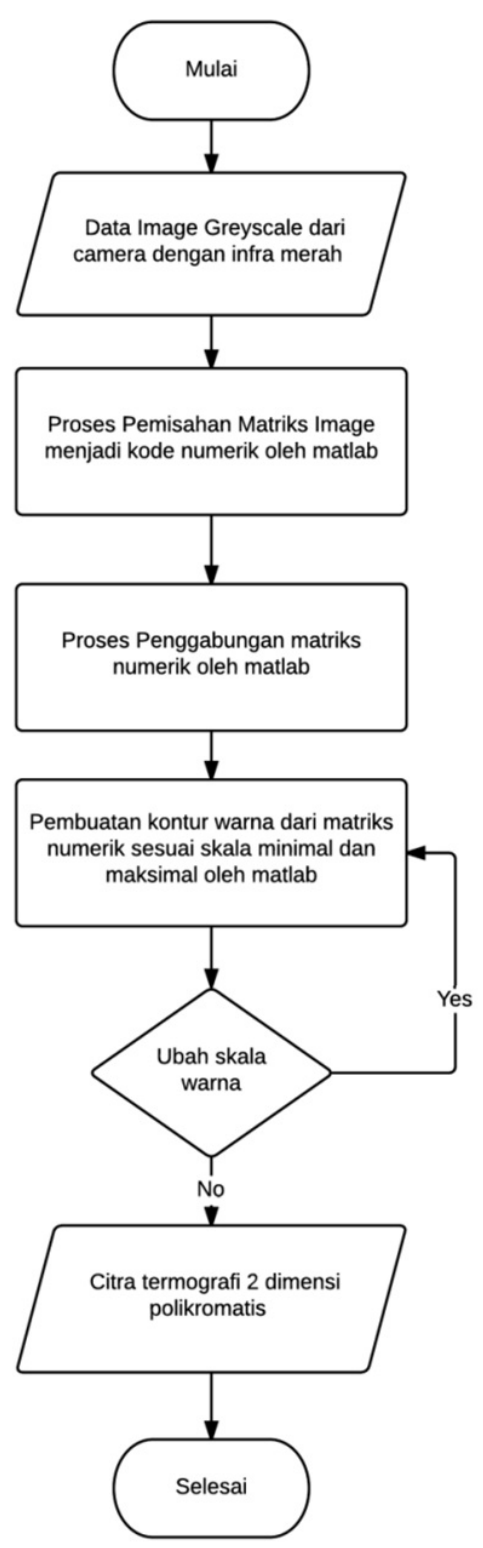

Gambar 2: Flowchart system.

warna berdasarkan nilai z. Gambar 1 menunjukan transformasi citra dari abu-abu menjadi polikromatis. Skala dapat diatur berdasarkan ketelitian yang diinginkan. Gambar 2 menunjukan diagram alir dari system ini.

\section{PEMBAHASAN}

\section{Pengambilan gambar grayscale (citra abu-abu) dengan kamera "night vision" dan infrared}

Pada tahap ini dilakukan pengambilan gambar menggunakan handycam dalam mode night vision (penglihatan

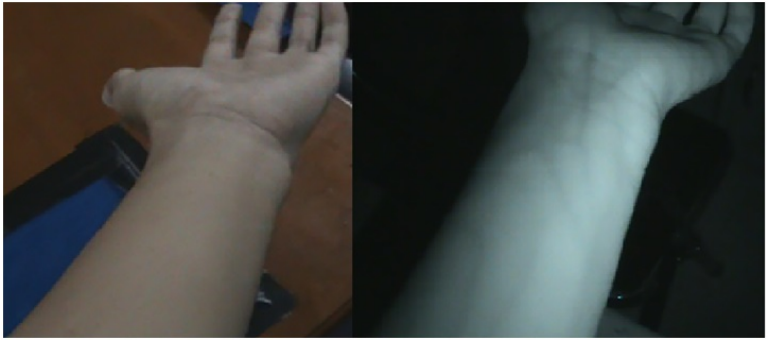

Gambar 3: Hasil gambar tanpa mode night vision dan infrared(kiri). Hasil gambar menggunakan mode night vision dan infrared(kanan).

malam) yang disertai dengan LED infrared. Gambar yang terbentuk berupa gambar abu-abu. Pada hasil pengambilan gambar juga terlihat bahwa infrared mampu menembus bagian kulit luar sehingga nampak berkas-berkas pembuluh darah vena setelah dilakukan pengambilan gambar dengan handycam mode night vision dan dengan tambahan interferensi dari LED infrared. Gambar 3 menunjukan perbedaan gambar yang diambil dari kamera mode biasa dan mode night vision dengan tambahan interferensi LED infrared.

\section{Pembuatan program image processing menggunakan Matlab.}

Pada dasarnya citra night vision yang diambil dari kamera handycam tersebut masih berupa citra polikromatis yang merupakan matriks 3 dimensi karena masih memiliki format RGB (Red, Green, Blue). Selanjutnya citra polikromatis tersebut diubah ke bentuk abu-abu (grayscale) dengan cara merubah matriks 3 dimensi menjadi 2 dimensi dimana layer (lapisan) citra RGB yang berjumlah tiga akan diubah menjadi layer (lapisan) BW (Black and White) yang memiliki 1 lapis saja. Sehingga citra yang semula merupakan perpaduan dari warna Red, Green, Blue (merah, hijau, biru) akan berubah menjadi citra 2 dimensi yang berisi tingkat keabu-abuan pada setiap titik. Berikut adalah skema perubahan matriks RGB ke matriks grayscale

$$
\begin{aligned}
R G B= & {\left[\begin{array}{lll}
(R, G, B)_{12} & (R, G, B)_{12} & (R, G, B)_{13} \\
(R, G, B)_{21} & (R, G, B)_{22} & (R, G, B)_{23} \\
(R, G, B)_{31} & (R, G, B)_{32} & (R, G, B)_{33}
\end{array}\right] } \\
B W= & {\left[\begin{array}{lll}
\left(\frac{R+G+B}{3}\right)_{31} & \left(\frac{R+G+B}{3}\right)_{32} & \left(\frac{R+G+B}{3}\right)_{33} \\
\left(\frac{R+G+B}{3}\right)_{21} & \left(\frac{R+G+B}{3}\right)_{22} & \left(\frac{R+G+B}{3}\right)_{23} \\
\left(\frac{R+G+B}{3}\right)_{11} & \left(\frac{R+G+B}{3}\right)_{12} & \left(\frac{R+G+B}{3}\right)_{13}
\end{array}\right] } \\
B W= & {\left[\begin{array}{lll}
B W_{31} & B W_{32} & B W_{33} \\
B W_{21} & B W_{22} & B W_{23} \\
B W_{11} & B W_{12} & B W_{13}
\end{array}\right] }
\end{aligned}
$$

Pada proses perubahan citra RGB ke grayscale ini matriks mengalami perubahan posisi terbalik secara vertikal. Agar posisi matriks dapat kembali seperti posisi awal maka matriks tersebut dibalik secara vertikal menggunakan fungsi flipup() 


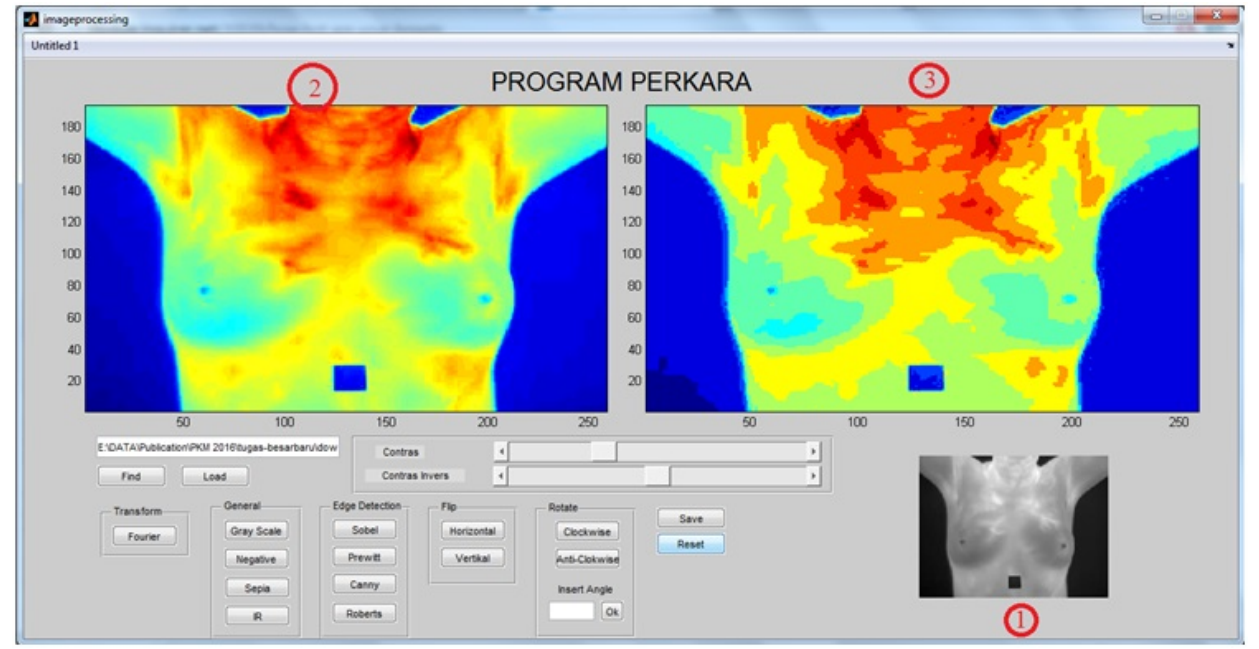

Gambar 4: Tampilan Program PERKARA (PENDETEKSI KANKER PAYUDARA).

pada matlab.

$$
\begin{aligned}
B W & =\operatorname{flipup}(B W) \\
B W & =\left[\begin{array}{lll}
B W_{11} & B W_{12} & B W_{13} \\
B W_{21} & B W_{22} & B W_{23} \\
B W_{31} & B W_{22} & B W_{23}
\end{array}\right]
\end{aligned}
$$

Selanjutnya matriks tersebut akan diubah menjadi sebuah citra polikromatis yang menggambarkan kontur warna berdasarkan tingkat keabu-abuan pada citra tersebut yang menggambarkan distribusi panas tubuh. Karena masih dalam bentuk matriks, maka hal yang harus dilakukan adalah merubah format matriks menjadi double. Hal ini dilakukan agar setiap koordinat dapat diketahui nilainya dengan merubah tipe data ke double. Setelah tipe data matriks dari citra abu-abu sudah menjadi array dengan tipe double maka selanjutnya adalah memploting array tersebut menjadi sebuah grafik kontur warna yang menggambarkan distribusi panas tubuh. Gambar 4 menunjukan tampilan program images processing menggunakan matlab.

Pada Gambar 4 bagian yang ditandai dengan nomor 1 merupakan gambar asli dari citra grayscale yang didapat dari handycam dengan mode night vision. Pada bagian yang ditandai dengan nomor 2 merupakan hasil images processing dari matlab yang mengubah citra abu-abu menjadi citra polikromatis yang dapat menunjukan dengan jelas distribusi panas tubuh seseorang. Pada bagian yang ditandai dengan nomor 3 merupakan hasil citra dari citra bagian 2 yang telah melalui proses perubahan kontras sehingga skala warna dapat berubah. Perubahan kontras ini berfungsi untuk mempertegas warna sehingga memudahkan analisa dokter tentang adanya potensi kanker payudara.

\section{Proses perubahan skala kontras pada program PERKARA}

Pada proses perubahan skala kontras dilakukan dengan mengubah intensitas pada matriks citra yang telah dirubah menjadi grafik kontur warna. Perubahan warna menggunakan slider yang akan otomatis akan merubah hasil citra saat slider digeser.

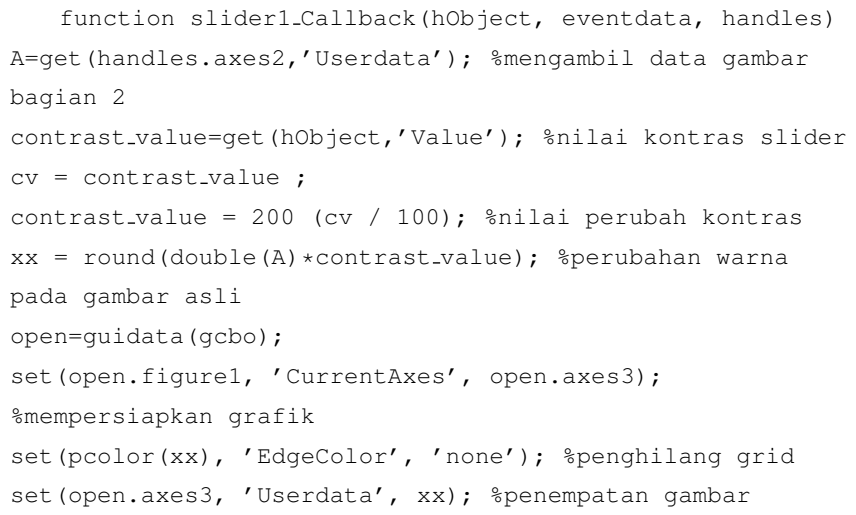

Selain itu perubahan konstras juga dapat dilakukan dengan invers kontras, atau merubah kontras dengan membalik skala warna sehingga citra dengan warna biru akan menjadi merah dan sebaliknya. Hal ini dilakukan untuk mengatasi bila gradasi suatu citra tidak terlalu jelas sehingga perlu skala warna lain untuk memperjelas gradasi dari citra tersebut.

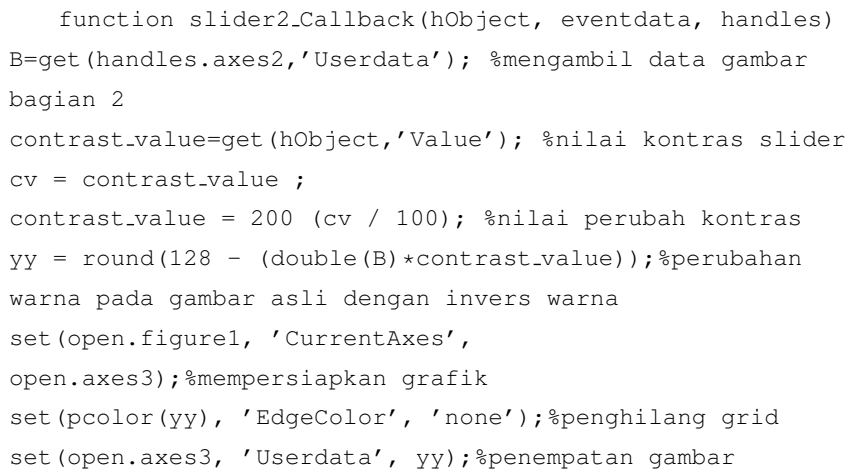




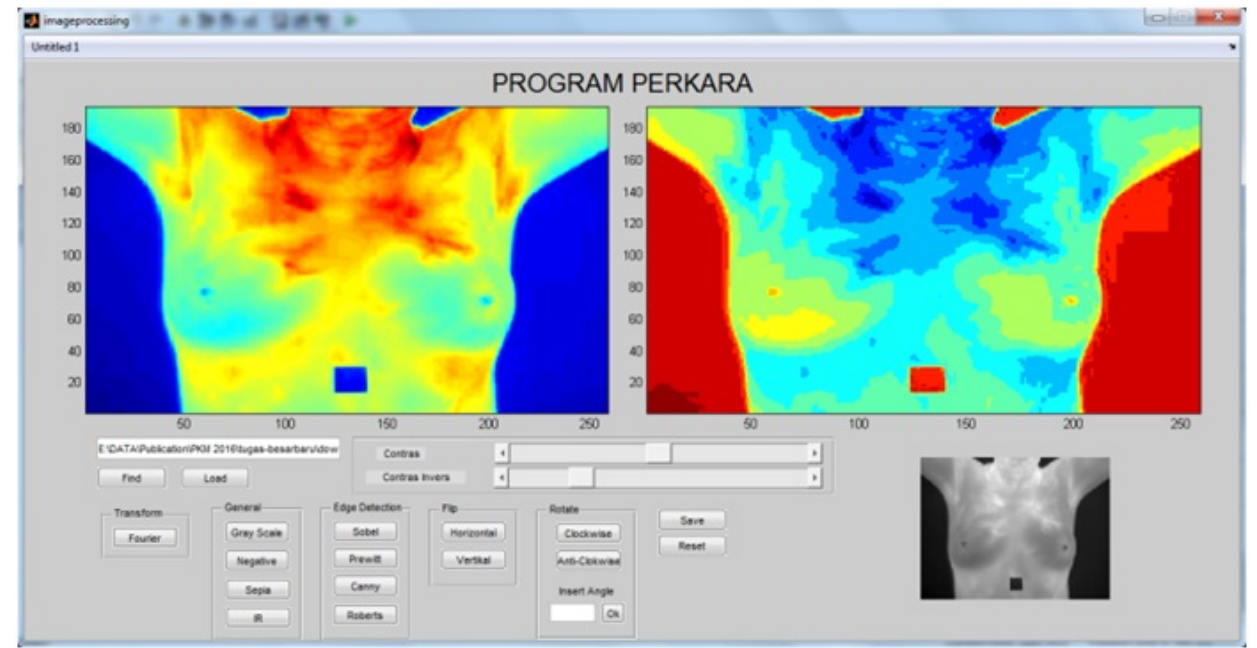

Gambar 5: Tampilan Program PERKARA (PENDETEKSI KANKER PAYUDARA) dengan pengubahan skala konstras invers.

Pada Gambar 5 ditujukan hasil dari pengolahan citra dengan invers kontras.

\section{SIMPULAN}

Handycam pada mode night vision yang diberi interferensi infrared eksternal dapat melakukan penetrasi ke kulit lebih baik dan dapat menjadikan citra infra merah menjadi lebih jelas. Gambar hasil dari handycam tersebut dapat diolah oleh Program PERKARA (Pendeteksi Kanker Payudara) dengan hasil kontras warna yang cukup jelas. Program PERKARA mampu mengubah gambar hitam-putih dari handycam menjadi citra termal dengan cara memecah struktur matriks RGB menjadi grayscale. Setelah itu matriks disusun ulang pada matriks baru dengan tipe data double sehingga dapat diproses menjadi grafik kontur warna yang dapat membedakan distribusi temperatur tubuh pada citra yang diolah. Pengolahan grafik tersebut dengan cara membedakan tingkat keabu-abuan citra tersebut sehingga didapatkan warna yang berbeda-beda. Pada Program Perkara terdapat pula fitur pengaturan skala kontras pada citra yang diolah sehingga kedetilan warna dapat diatur sesuai keinginan. Selain itu juga ada firut pengaturan skala kontras invers yang berguna untuk membalik skala warna sehingga warna dapat berubah menjadi sebaliknya.
[1] Novianti, Fourina Ayu dan Santi Wulan Purnami, Analisis Diagnosis Pasien Kanker Payudara Menggunakan Regresi Logistik dan Support Vector Machine (SVM) Berdasarkan Hasil Mamografi, POMITS 1(1),(2012) [http://ejurnal.its.ac.id/index.php/sains_seni/article/viewFile/1937/317 (07/18/2016)]

[2] Dinas Kesehatan Nasional, Jika Tidak Dikendalikan 26 Juta Orang di Dunia Menderita Kanker, 2010. [http://www.depkes.go.id/article/view/1060/jika-tidakdikendalikan-26-juta-orang-di-dunia-menderita-kanker-.html] (07/18/2016)

[3] X. Maldague, Theory and Practice of Infrared Technology for
Nondestructive Testing (Wiley, New York, NY, USA, 2001).

[4] M.F. Modest, Radiative Heat Transfer (Academic Press: Waltham, MA, USA, 2013).

[5] G. Gaussorgues, Infrared Thermography (Springer: Berlin/Heidelberg, Germany, 1994).

[6] M. EtehadTavakol, E.Y.K. NG, J. Mech. Med. Biol., 13, 1330001 (2013).

[7] A. Dhungana, Segmentation of Infrared Images, Thesis, Texa Tech University, 2002.

[8] N.R. Pal, S.K. Pal, Pattern Recognit., 26, 1277-1294 (1993). 